\title{
Model Forest Tree dalam Sistem Informasi Gamelan Terintegrasi
}

\author{
Forest Tree Model in Integrated Gamelan Bali Information System
}

\author{
Oka Sudana ${ }^{1}$, I Putu Krisna Cahaya Putra ${ }^{2}$, Ayu Wirdiani ${ }^{3}$ \\ 1,2,3Program Studi Teknologi Informasi/Jurusan Teknik, Universitas Udayana \\ E-mail: ${ }^{1}$ agungokas@unud.ac.id, ${ }^{2}$ tgkrisna@gmail.com, ${ }^{3}$ ayuwirdiani@unud.ac.id
}

\begin{abstract}
Abstrak
Gamelan Bali merupakan alat musik tradisional yang menonjolkan metalofon, gambang, kendang, dan gong. Salah satu fungsi Gamelan Bali adalah untuk mengiringi upacara keagamaan khususnya di Bali. Selain itu Gamelan Bali juga memiliki kaitan erat dengan Budaya Bali lainnya seperti Tari Bali dan Kidung. Permasalahan yang terjadi di masyarakat saat ini yaitu disinformasi mengenai penggunaan Gamelan Bali dalam mengiringi Upacara Keagamaan, Tari Bali, dan Kidung. Berdasarkan permasalahan tersebut, maka dibangun sebuah sistem informasi berbasis web yang terintegrasi antara Upacara Keagamaan, Gamelan Bali, Tari Bali dan Kidung. Untuk mendukung proses yang terjadi didalam sistem informasi tersebut, maka digunakanlah model Forest Tree yang merupakan pengembangan dari model Tree. Model Forest Tree digunakan karena banyaknya entitas, dan juga kasus unik dimana ada keterkaitan antara child dengan child dalam satu parent, dimana model Tree tidak bisa mengakomodir hal tersebut. Tujuan dari dilakukannya penelitian ini adalah memberikan edukasi kepada masyarakat untuk mengenal Gamelan Bali beserta kaitannya. Metode pengumpulan data yang digunakan adalah studi literatur dan wawancara. Hasil yang didapatkan dari penelitian ini adalah model Forest Tree yang berdasarkan pengembangan dari dua Model Tree yaitu Gamelan Bali dan Upacara.
\end{abstract}

Kata kunci: Sistem Informasi, Gamelan Bali, Upacara, Web, Model Forest Tree

\begin{abstract}
Balinese gamelan is a traditional musical instrument that features metallophones, xylophone, drums, and gongs. One of the functions of Balinese Gamelan is to accompany religious ceremonies, especially in Bali. Besides that, Balinese Gamelan also has close links with other Balinese culture such as Balinese Dance and Kidung. The problem that occurs in the community today is the disinformation regarding the use of Balinese Gamelan in accompanying Religious Ceremonies, Balinese Dance, and Kidung. Based on these problems, a web-based information system was built that integrated the Religious Ceremony, Balinese Gamelan, Balinese Dance, and Kidung. To support the processes that occur in the information system, the Forest Tree model is used which is a development of the Tree model. The Forest Tree model is used because of the many entities, and also the unique case where there is a relationship between child and child in one parent, where the Tree model cannot accommodate that. The purpose of this research is to provide education to the public to get to know the Balinese Gamelan and its links. Data collection methods used are literature studies and interviews. The results obtained from this study are the Forest Tree model based on the development of two Model Trees namely Balinese Gamelan and Ceremony.
\end{abstract}

Keywords: Information Systems, Balinese Gamelan, Ceremony, Web, Forest Tree Model

\section{PENDAHULUAN}

Kendala ruang dan waktu dalam mengakses sebuah informasi bisa dijawab dengan kemajuan teknologi informasi. Hal inipun terjadi pada saat mengakses informasi mengenai Gamelan Bali, dimana Gamelan Bali merupakan salah satu kebudayaan yang khas dari Bali [1]. 
Budaya sendiri merupakan satu kesatuan yang tidak bisa dipungkiri membangun peradaban masyarakat [2], hal ini juga berlaku dalam Gamelan Bali. Gamelan Bali merupakan alat musik (bentuk fisik) dimana menonjolkan metalofon, gambang, kendang, dan gong [3]. Namun kondisi yang terjadi saat ini, masyarakat mulai melupakan budaya dikarenakan datangnya budaya baru yang lebih menarik seperti halnya budaya asing [4]. Selain itu kurangnya minat pada budaya dalam bentuk fisik [5], juga terjadi disinformasi dalam masyarakat mengenai Gamelan Bali beserta kaitannya. Untuk menjawab kendala ruang dan waktu, sistem informasi menjadi jawaban, dimana saat ini hanya sedikit sistem informasi yang membahas mengenai seni dan budaya [6].

Dari permasalahan tersebut dibangunlah sebuah Sistem Informasi Gamelan Bali Terintegrasi menggunakan model Forest Tree sebagai basis dari sistem. Model Forest Tree digunakan sebagai dasar dari sistem informasi nantinya, dimana model ini sangat membantu untuk menghubungkan banyak entitas dengan kondisi dimana antara child dengan child dalam satu parent saling berkaitan berbeda dengan model Tree yang tidak diperbolehkan adanya keterkaitan antara satu child dengan yang lainnya dalam sebuah parent [7]. Serta terdapat proses Copy-References dimana menghindari ketika sebuah entitas harus memiliki value yang unik yang diambil dari keterkaitan antar entitas. Pembuatan sistem informasi ini bertujuan untuk mencegah disinformasi mengenai Gamelan Bali beserta kaitannya dengan upacara keagamaan atau yang disebut sebagai Upacara Yadnya maupun budaya bali seperti Tari Bali dan Kidung.

Penelitian sebelumnya berkaitan dengan model Forest Tree dimana objek yang diteliti adalah aplikasi yang diduga malware yang merusak smartphone Android. Hal ini didasari oleh aplikasi Android yang mudah didapat dikarenakan gratis dan tersebar di banyak Android Store. Banyak dari aplikasi tersebut belum tersertifikasi, oleh karena itu bisa saja aplikasi ini merupakan malware yang mencuri data pengguna smartphone Android. Cara kerja untuk mendeteksi apakah aplikasi Android tersebut malware atau bukan dengan menggunakan machine learning yang melakukan pemantauan pada banyak permissionbased dan dicocokan dengan permissionbased yang dimiliki oleh aplikasi Android [8].

Penelitian mengenai metode Forest Tree pada aktvitas biologis untuk metode klasifikasi baru dalam mengidentifikasi pengikatan RNA dalam protein dengan menggabungkannya menggunakan fitur baru (fitur ini berdasarkan urutan dan struktur lainnya). Proses lebih lanjut, interaksi mewakili secara spesifik dari terikatnya residu protein ke nukleotida RNA dengan mempertimbangkan interaksi lingkungan dua sisi dalam triplet residu protein. Proses pengurutan serta fitur berbasis struktur dari residu digabungkan bersama dengan tujuan untuk membedakan interaksi antara asam amino dengan RNA. Random Forest digunakan untuk memprediksi interaksi antara RNA dengan residu dalam protein. Hasil dari eksperimen ini menunjukkan bahwa metode Random Forest dengan fitur gabungan ini dapat mendeteksi lokasi interaksi protein-RNA dalam akurasi yang tinggi. Metode ini mencapai akurasi sebesar 84,5\%. Metode ini lebih unggul daripada beberapa mesin prediksi lainnya yang mengikat RNA seperti RNABindR, BindN, RNAProB, dan PPRint dan beberapa metode algoritma dalam mesin prediksi seperti Naïve Bayes dan Neural Network [9].

Penelitian lainnya mengenai aplikasi alat musik daerah, dimana tujuan dari aplikasi ini adalah adalah pengenalan alat musik tradisional di provinsi yang ada di Indonesia. Metode yang digunakan pada penelitian ini merupakan metode pengembangan multimedia. Pendekatan multimedia merupakan pendekatan yang melalui beberapa proses seperti concept, design, manual collecting, assembly, testing, distribution [10].

Penelitian lainnya terkait dengan Upacara khususnya dalam pemetaan Pura Kawitan beserta relasinya (termasuk Upacara yang diadakan dalam Pura tersebut). Penelitian ini menggunakan metode Tree dengan memanfaatkan GIS (Geographic Information System) sebagai lokasi dimana Pura Kawitan tersebut berada. Metode Tree sendiri digunakan untuk memudahkan proses dalam menemukan keterkaitan antara entitas Pura Kawitan dengan tempat, status, fungsi (salah satunya adalah Upacara yang diadakan dalam Pura Kawitan tersebut) [11]. Penelitian yang khusus mengenai Prosesi Upacara sudah dilakukan sebelumnya, dengan menggunakan model Tree sebagai basis. Penelitian ini meneliti bagaimana keterkaitan antara Upacara dengan Prosesi 
Upacara beserta tata cara pelaksanaan dan tempat pelaksanaanya [12].

Penelitian mengenai metode Tree yang merupakan dasar dari Model Forest Tree digunakan dalam pencarian item dalam E-Commerce. Proses yang dilakukan adalah proses pencarian secara semantik, dimana pencarian semantik dianalisis dalam setiap kata pencarian. Tahap awal pengguna akan diminta memasukkan kata kunci yang ingin ditemukkan dalam $E$ Commerce. Tahap selanjutnya adalah tahapan preprocessing dari perhitungan dan normalisasi dengan cosinus yang disetujui. Hasil yang diperoleh adalah kata-kata terkait dari skor tertinggi ke skor terendah [13]. Penelitian yang terkait metode Tree sebagai basis dari model Forest Tree juga telah dilaksanakan dengan objek penelitian yaitu Jajanan Tradisional Bali. Penelitian ini melakukan pemetaan mengenai Jajanan Tradisional Bali baik dari cara pembuatan, bahan, serta fungsi secara umum dalam masyarakat [14].

Berdasarkan penelitian diatas, maka model baru dibuat berdasarkan model Tree, yaitu Forest Tree dimana merupakan perluasan dari model Tree. Model ini terinspirasi dari metode Forest Tree dimana terdiri dari banyak Tree, tetapi tidak dibuat untuk tujuan perhitungan atau peramalan tetapi untuk memodelkan hubungan antara entitas. Untuk memudahkan menyalurkan informasi dengan model ini, digunakanlah sebuah sistem informasi berbasis web, dimana terdiri dari Gamelan Bali, Upacara Yadnya, serta entitas terkait seperti Tabuh, Tari Bali, Kidung, Mantram. Diharapkan dengan sistem informasi ini nantinya masyarakat mudah untuk mengakses mengenai Gamelan Bali yang digunakan dalam suatu Upacara Yadnya beserta entitas terkait.

\section{METODE PENELITIAN}

Metode penelitian dalam model Forest Tree Sistem Informasi Gamelan Bali Terintegrasi meliputi alur penelitian, gambaran umum sistem, dan diagram konteks.

\subsection{Alur Penelitian}

Alur penelitian dari Model Forest Tree dalam Sistem Informasi Gamelan Bali Terintegrasi dapat digambarkan seperti Gambar 1.

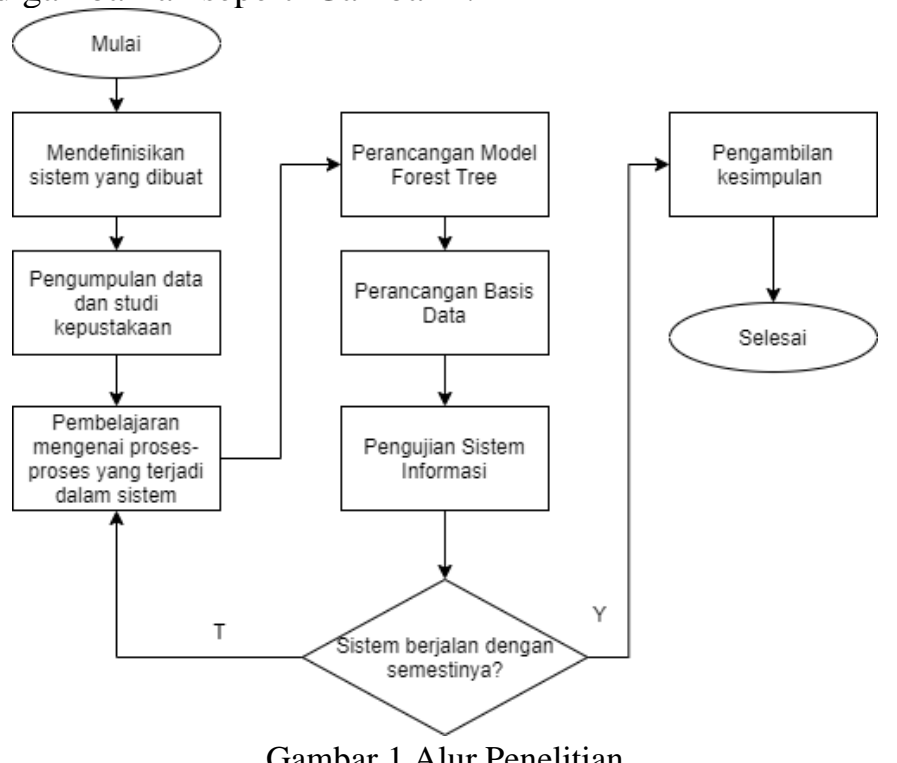

Gambar 1 Alur Penelitian

Gambar 1 merupakan alur penelitian dalam Model Forest Tree dalam Sistem Gamelan Bali Terintegrasi. Proses awal yaitu mendefinisikan sistem yang dibuat yaitu Sistem Informasi Gamelan Bali dengan Model Forest Tree sebagai basisnya. Proses dilanjutkan dengan pengumpulan data dan studi kepustakaan yang sesuai dengan Sistem Informasi Gamelan Bali nantinya. Lalu dilanjutkan dengan pembelajaran mengenai proses yang terjadi nantinya dalam sistem mulai dari proses pembentukkan parent-child hingga penghapusan parent-child. Proses 
selanjutnya adalah perancangan model Forest Tree sesuai dengan fakta dilapangan, dimana entitas yang terkait dengan Gamelan Bali akan ditampilkan. Perancangan basis data sangat penting dalam proses ini, hal ini guna mencakup data dengan keterkaitan banyak entitas. Proses setelah diadakan pengujian sistem informasi adalah pengecekan, apakah sistem berjalan sebagaimana mestinya. Jika sistem berjalan sebagaimana mestinya maka diadakan proses pengambilan kesimpulan. Jika tidak maka diulang menuju proses pembelajaran mengenai proses yang terjadi nantinya dalam sistem informasi.

\subsection{Model Forest Tree}

Metode Forest Tree adalah skema yang diusulkan oleh Leo Breiman pada tahun 2000 dengan tujuan untuk membangun algoritma prediktif dengan sejumlah pohon keputusan [15]. Pendekatan Forest Tree yang dikemukakan oleh Leo Breiman adalah setiap pohon dalam koleksi dibentuk dengan terlebih dahulu memilih secara acak pada masing-masing node. Sekelompok kecil input (juga disebut sebagai fitur atau variabel) yang dihitung berdasarkan fitur yang ada dalam training set. Berbeda dengan metode Forest Tree, model Forest Tree lebih kepada pengembangan dari model Tree, dimana model Tree sendiri memiliki kekurangan yaitu pada proses keterkaitan. Proses keterkaitan disini adalah antara child dengan child pada satu parent, dimana pada model Forest Tree hal ini sering terjadi. Selain itu model Forest Tree terdapat proses Copy-References dimana menghindari ketika sebuah entitas harus memiliki value yang unik yang diambil dari keterkaitan antar entitas.
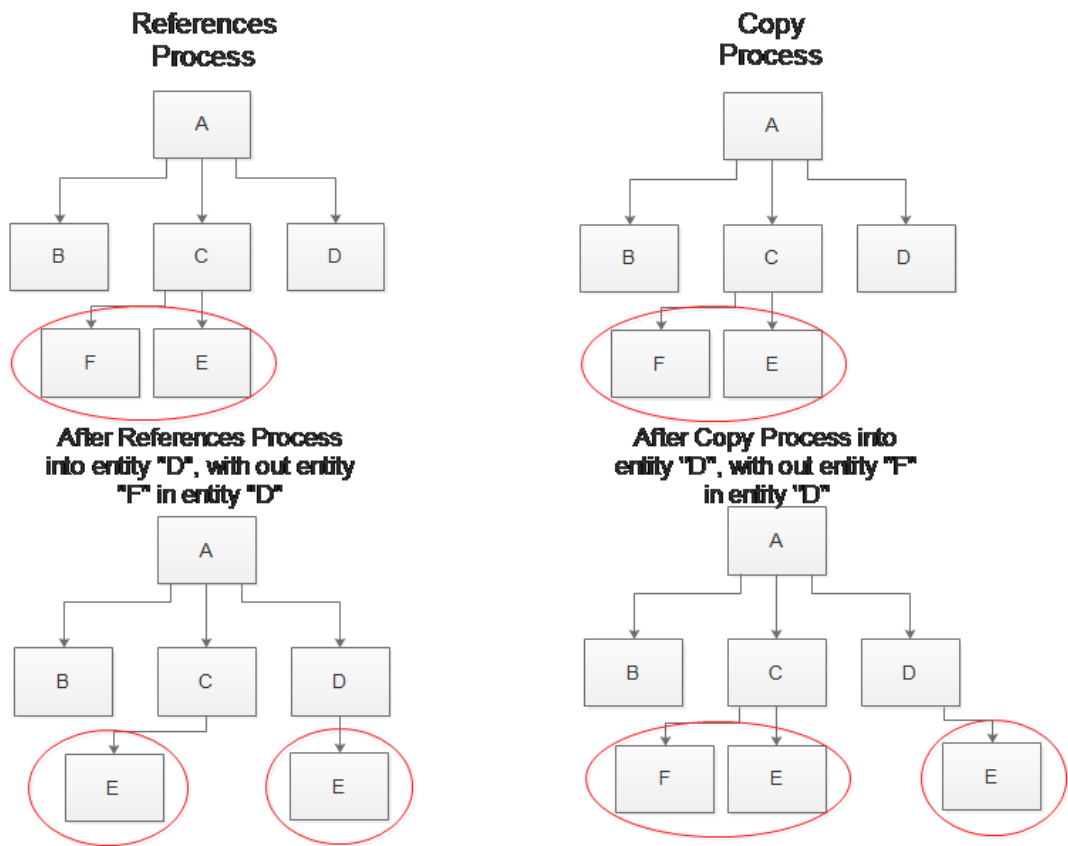

Gambar 2 Proses Copy-References

Gambar 2 merupakan logika dari proses Copy-References, dimana logika ini nantinya akan digunakan untuk entitas yang memiliki kondisi khusus dimana sebuah entitas yang memiliki child, dan entitas tersebut digunakan pada entitas lain sebagai child (dimana informasi child sebelumnya otomatis terbawa yang termasuk proses References). Tetapi ada kondisi dimana dalam sebuah Forest Tree, salah satu atau banyak child tidak dibutuhkan, oleh karena itu proses Copy ada. Proses Copy-References ini sangat berguna nantinya dikarenakan tidak terikat dengan kaidah Tree (kaitan antara child dengan child). 


\subsection{Metode Pengumpulan Data}

Metode pengumpulan data yang digunakan dalam penelitian ini dibagi menjadi dua yaitu studi literatur dan wawancara. Studi literatur dilakukan dengan cara mengumpulkan data dari referensi buku maupun jurnal [16], dimana berkaitan langsung dengan budaya atau model Forest Tree. Wawancara dilakukan dengan melakukan melakukan tanya jawab secara langsung dengan narasumber yang merupakan seorang pakar dalam bidang Gamelan Bali.

\subsection{Gambaran Umum Sistem}

Gambaran umum sistem dari Model Forest Tree dalam Sistem Informasi Gamelan Bali Terintegrasi dapat digambarkan seperti Gambar 3.

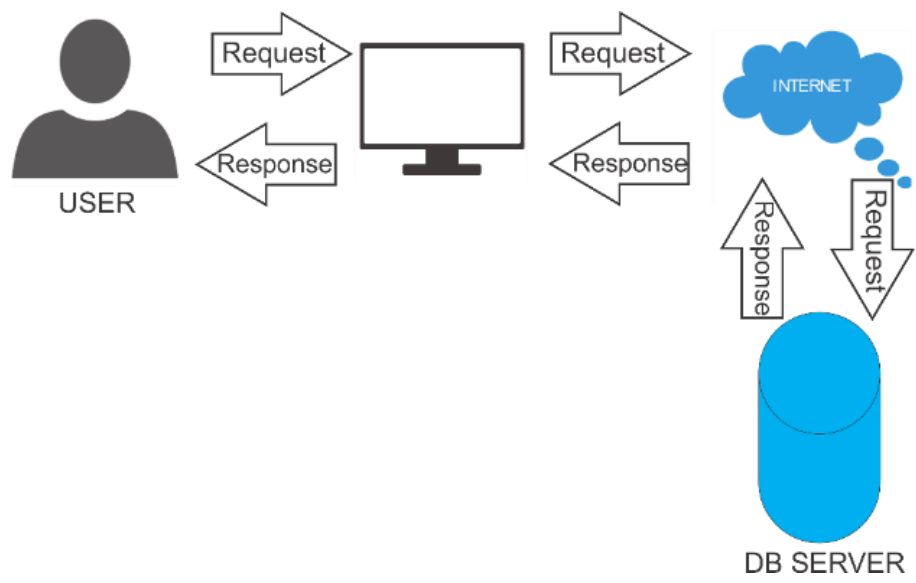

Gambar 3 Gambaran Umum Sistem

Gambar 3 menjelaskan secara umum bagaimana nantinya Sistem Informasi Gamelan Bali berjalan. Entitas User sendiri dibagi menjadi dua, yaitu Administrator selaku pengatur informasi, dan Pengguna secara umum sebagai penerima informasi. Sistem informasi ini nantinya akan terhubung dengan entitas User melalui platform yang bisa mengakses Internet dan Web untuk membuka tampilan dari Sistem Informasi Gamelan Bali. Proses penyimpanan data dari sistem informasi ini menggunakan database server dengan tujuan untuk menyimpan data yang cukup besar nantinya yang diolah menjadi informasi.

\subsection{Diagram Konteks}

Diagram konteks dari Model Forest Tree dalam Sistem Informasi Gamelan Bali Terintegrasi dapat digambarkan seperti Gambar 4.

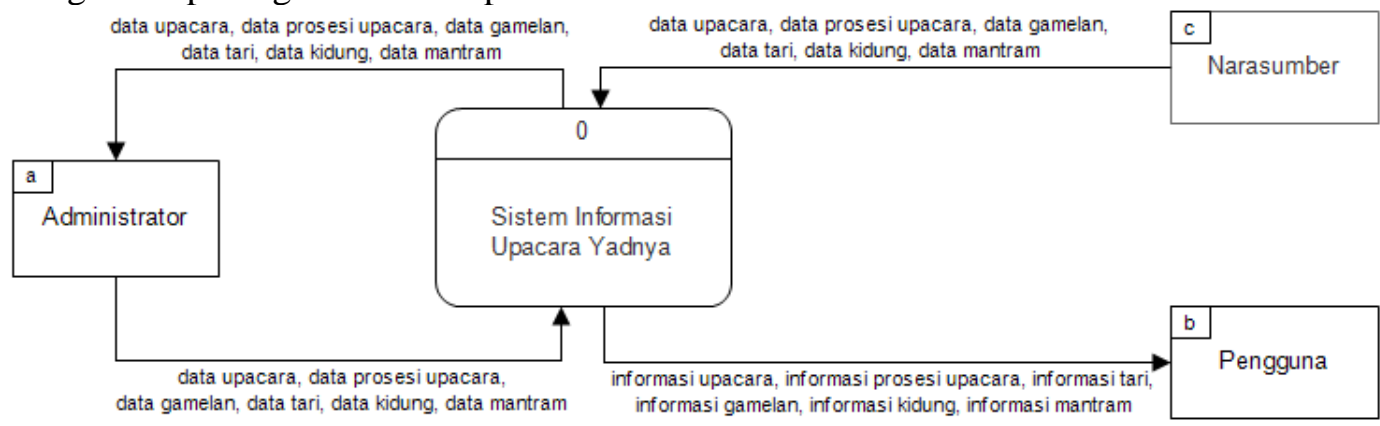

Gambar 4 Diagram Konteks

Gambar 4 merupakan diagram konteks dari Sistem Informasi Gamelan Bali dengan Model Forest Tree, di mana fungsionalitas dari pengguna dibagi menjadi tiga yaitu administrator, pengguna, dan narasumber. Administrator merupakan pengguna yang akan memasukkan dan menyunting data dari Upacara Yadnya, Prosesi Upacara, Gamelan Bali, Parent antara Upacara dengan Prosesi Upacara, serta Parent Upacara dengan Gamelan Bali. Pengguna memiliki fungsi 
untuk menerima informasi yang telah dimasukkan oleh administrator. Narasumber memiliki fungsi sebagai validator untuk mengecek apakah data yang akan dimasukkan oleh administrator sudah valid atau belum.

\section{HASIL DAN PEMBAHASAN}

Hasil dan pembahasan mencakup hasil Model Forest Tree yang didapat dari data atau fakta dilapangan, antarmuka User, dan kehandalan sistem.

\subsection{Model Forest Tree}

Model Forest Tree yang digunakan dalam Sistem Informasi Gamelan Bali didapat dari hasil pengamatan langsung dari banyak Upacara yang diadakan di Bali serta literasi kuno. Selain hal tersebut model Forest Tree dibagun dari banyak model Tree yang didapat dari banyaknya entitas yang terlibat. Upacara keagamaan atau yang sering disebut sebagai Upacara Yadnya di Bali sendiri memiliki keterkaitan langsung dengan banyak kegiatan atau yang disebut sebagai entitas dalam penelitian ini. Entitas tersebut yaitu Gamelan Bali, Tari Bali, Kidung, Mantram, Tabuh, dan Prosesi Upacara Yadnya. Akar dari pelaksanaan Upacara Yadnya tersebut yaitu Yadnya yaitu kurban suci yang dilaksanakan dengan tulus ikhlas dalam ajaran Agama Hindu [17]. Berikut ini merupakan model Tree yang didapat dari beberapa entitas.

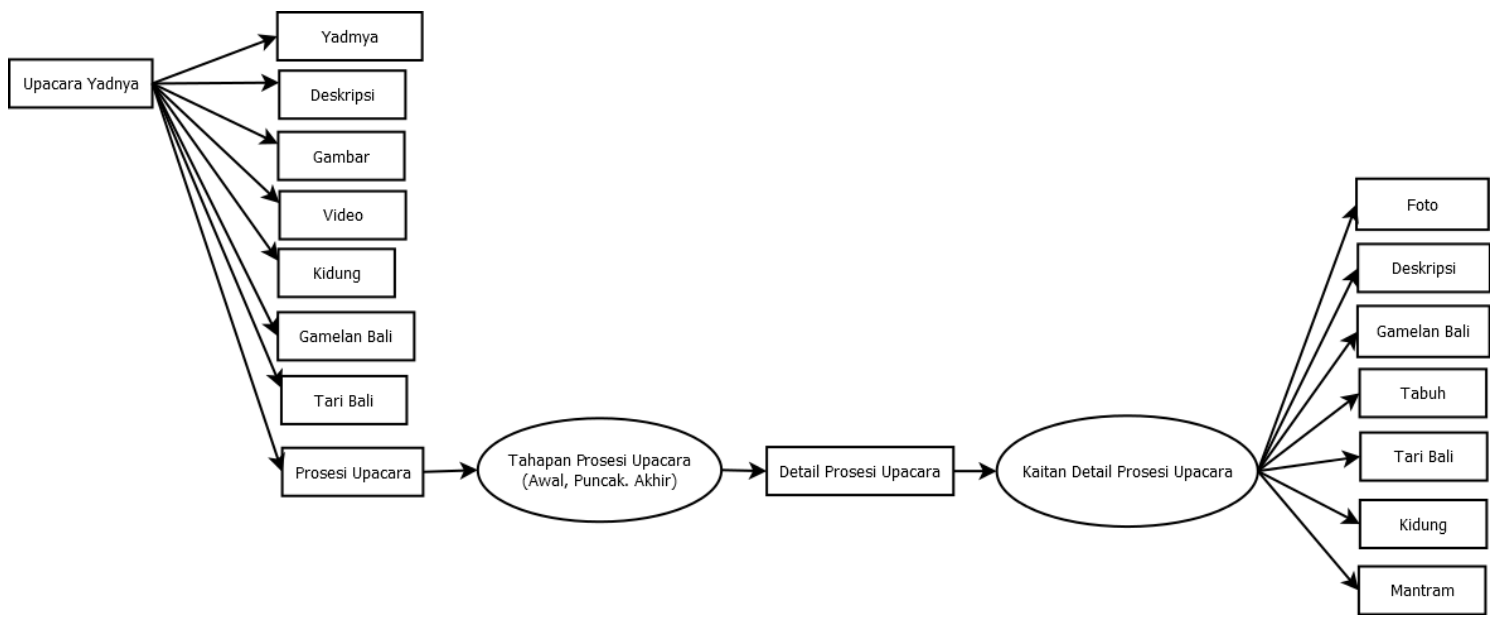

Gambar 5 Model Tree Upacara Yadnya

Gambar 5 merupakan model Tree dari Upacara Yadnya dimana terdiri atas banyak entitas yang membangunnya. Nantinya terdapat Gamelan Bali yang digunakan dalam suatu Upacara Yadnya, selain itu Upacara Yadnya bisa memiliki banyak Prosesi Upacara Yadnya yang dibagi menjadi tahapan Awal, Puncak, dan Akhir. Detail dari Prosesi Upacara tersebut memiliki banyak entitas terkait, dimana terdapat Gamelan Bali beserta Tabuh yang digunakan. 


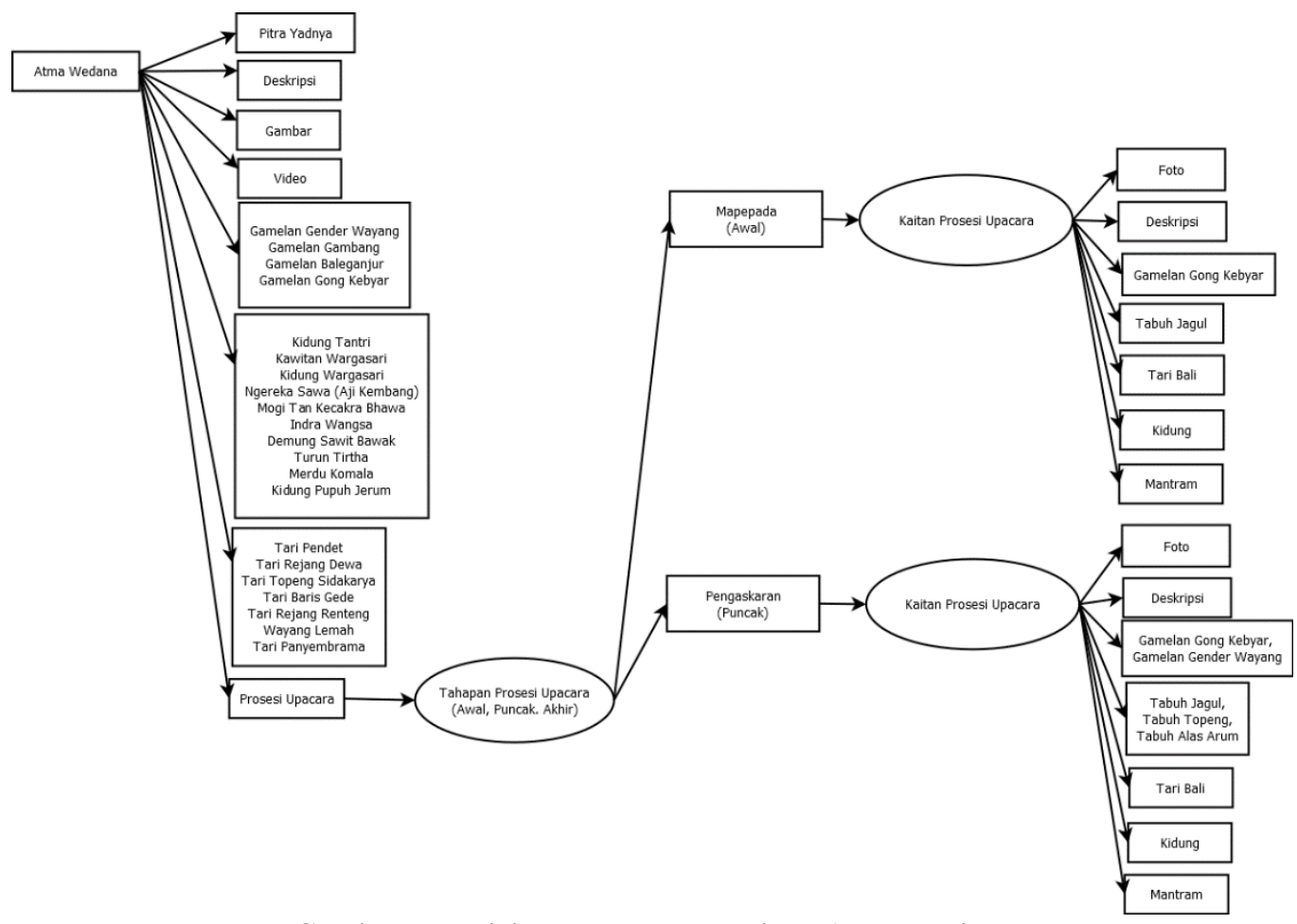

Gambar 6 Model Tree Upacara Yadnya Atma Wedana

Gambar 6 merupakan model Tree dari Upacara Yadnya yang bernama Atma Wedana dimana termasuk kedalam Pitra Yadnya, entitas Yadnya dibagi menjadi lima yaitu Dewa Yadnya, Manusa Yadnya, Pitra Yadnya, Rsi Yadnya, Bhuta Yadnya [18]. Data Gamelan Bali pada upacara ini merupakan himpunan dari masing-masing Prosesi Upacara yang ada. Entitas Tabuh pada Prosesi Upacara merujuk pada entitas Gamelan Bali yang digunakan oleh prosesi upacara tersebut.

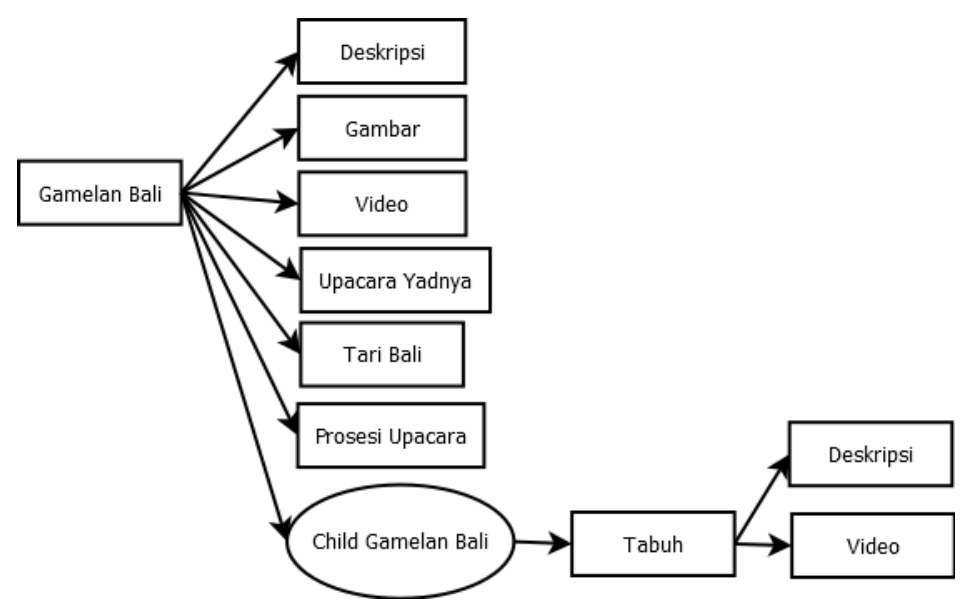

Gambar 7 Model Tree Gamelan Bali

Gambar 7 merupakan model Tree dari Gamelan Bali, dimana Gamelan Bali memiliki child yaitu Tabuh. Tabuh merupakan lagu yang dimainkan dalam Gamelan Bali yang biasanya digunakan dalam mengiringi suatu Prosesi Upacara atau Tari Bali [19]. 


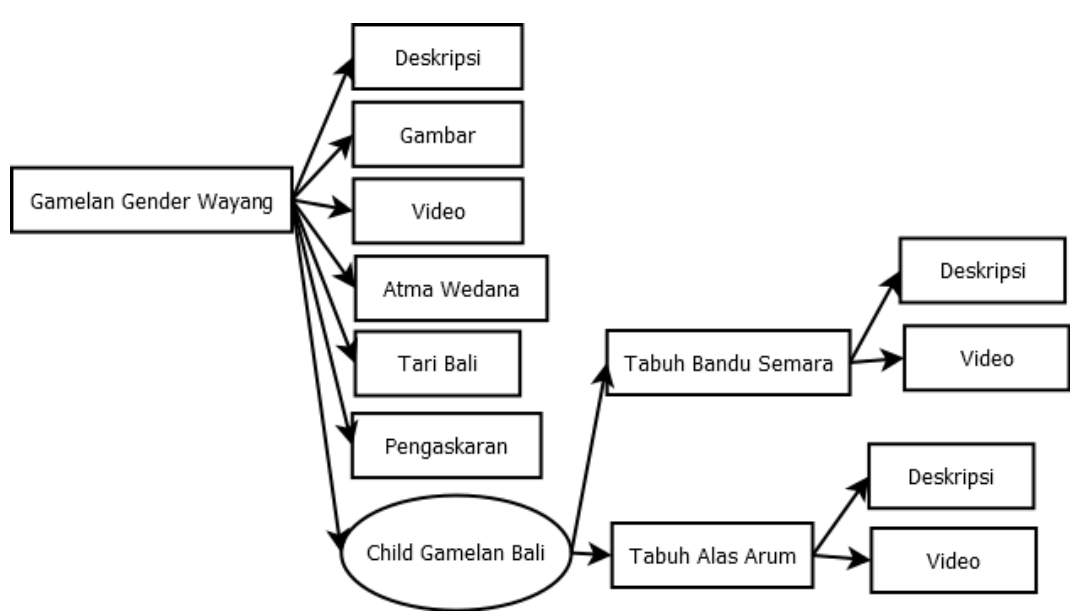

Gambar 8 Model Tree Gamelan Bali Gender Wayang

Gambar 8 merupakan model Tree dari Gamelan Bali yang bernama Gender Wayang. Gender Wayang sendiri digunakan dalam Upacara Yadnya Atma Wedana, dan Prosesi Upacara yaitu Pengaskaran. Dengan entitas yang saling berkaitan jika berkiblat antara Tree Upacara Yadnya dengan Gamelan Bali maka dapat digambarkan model Forest Tree seperti berikut.

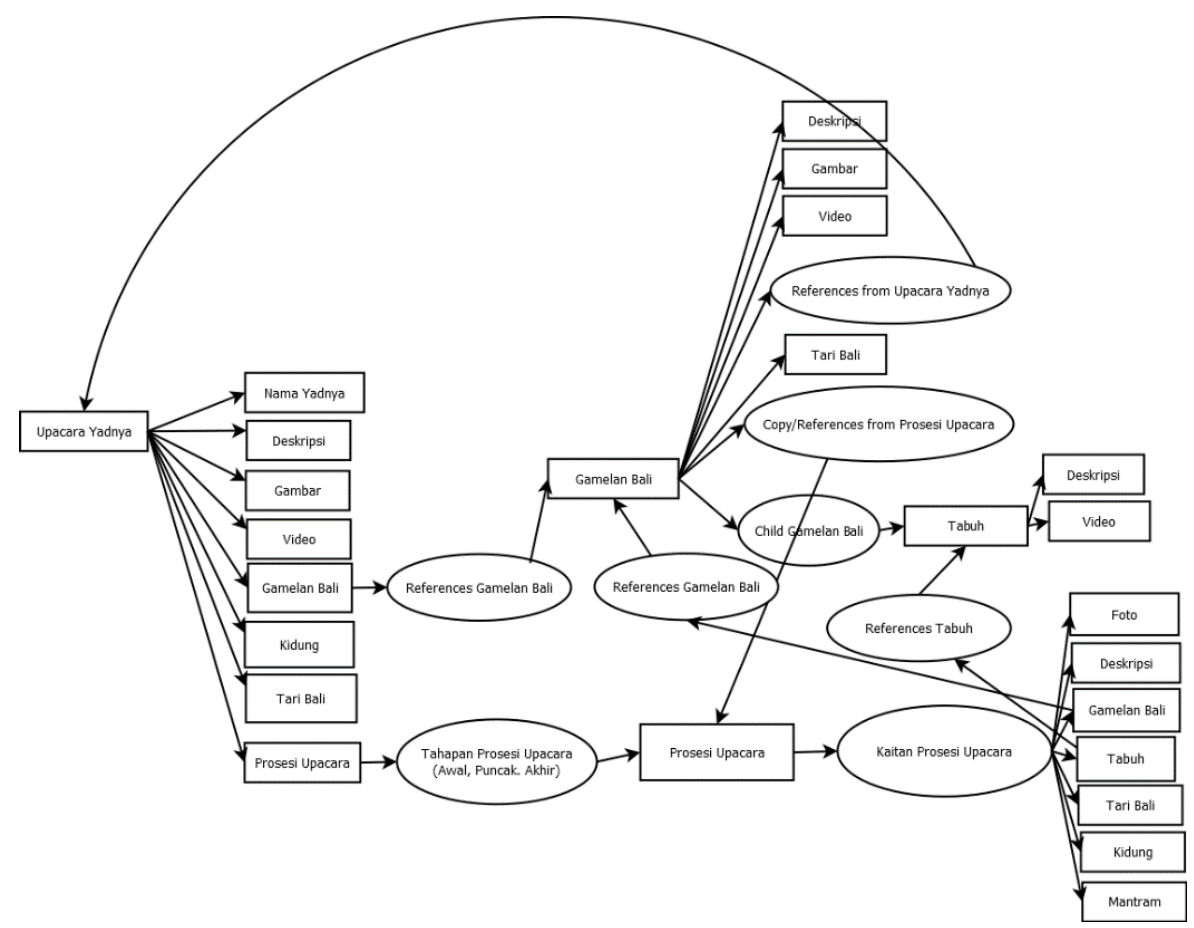

Gambar 9 Model Forest Tree

Gambar 9 merupakan model Forest Tree yang dibangun berdasarkan fakta yang terdapat dilapangan dan literasi kuno mengenai Upacara Yadnya dan Gamelan Bali. Terdapat banyak entitas yang terkait dalam suatu Upacara Yadnya dan Gamelan Bali. Tetapi hal tersebut menjadi masalah jika dilihat dari kaidah Tree, yaitu hubungan antara entitas yang berposisi sebagai child tidak diperbolehkan saling berkaitan dengan child lainnya. Selain hal tersebut terdapat hal yang unik yang terjadi dalam proses pengumpulan data, dimana entitas Prosesi Upacara memiliki keterkaitan langsung antara entitas Gamelan Bali, Tari Bali, Kidung, Tabuh, atau Mantram yang nantinya akan digunakan dalam beberapa Upacara Yadnya, tetapi entitas Gamelan Bali, Tari Bali, Kidung, Tabuh, atau Mantram yang terkait langsung dengan entitas Proses Upacara bisa berbeda 
antar Upacara Yadnya. Oleh karena itu model Forest Tree digunakan, dimana mendukung hal tersebut, yang disebut sebagai proses Copy-References yang telah dijelaskan sebelumnya pada Gambar 2.

\subsection{Perbandingan Forest Tree dengan Model Tree}

Perbandingan model Forest Tree yang telah dibuat sebelumnya, dibandingkan dengan model Tree pada penelitian sebelumnya. Perbandingan ini dilakukan untuk mencari kelebihan dan kekurangan dalam implementasi model Forest Tree dan model Tree dalam sistem informasi. Perbandingan yang digunakan dalam hal ini adalah penelitian yang berjudul Pemodelan Sistem Informasi Gamelan Bali menggunakan Tree Diagram, dan Information System of Yadnya Ceremony on Android-Based dimana kedua penelitian ini berfokus pada Gamelan Bali dan Prosesi Upacara Yadnya dengan menggunakan model Tree sebagai basis [3, 12].

\begin{tabular}{|c|c|c|c|}
\hline $\begin{array}{c}\text { Acuan } \\
\text { Perbandingan }\end{array}$ & $\begin{array}{c}\text { Model Forest Tree dalam } \\
\text { Sistem Informasi Gamelan } \\
\text { Terintegrasi }\end{array}$ & 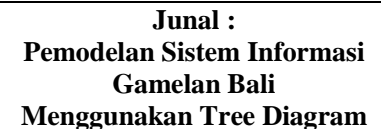 & $\begin{array}{c}\text { Jurnal : } \\
\text { Information System of Yadnya } \\
\text { Ceremony on Android-Based }\end{array}$ \\
\hline Studi Kasus & $\begin{array}{c}\text { Penerapan Model Forest Tree } \\
\text { pada Sistem Informasi } \\
\text { Gamelan Bali Terintegrasi }\end{array}$ & $\begin{array}{c}\text { Penerapan Model Tree pada } \\
\text { Sistem Informasi Gamelan Bali }\end{array}$ & $\begin{array}{c}\text { Penerapan Model Tree pada Sistem } \\
\text { Informasi Prosesi Upacara Yadnya } \\
\text { pada platform Android }\end{array}$ \\
\hline Latar Belakang & $\begin{array}{c}\text { Disinformasi dalam masyarakat } \\
\text { mengenai penggunaan } \\
\text { Gamelan Bali dalam Upacara } \\
\text { Yadnya, Tari Bali, dan Lagu } \\
\text { dari Gamelan Bali tersebut }\end{array}$ & $\begin{array}{c}\text { Kesalahan penggunaan Gamelan } \\
\text { Bali dalam mengiringi Upacara } \\
\text { Yadnya }\end{array}$ & $\begin{array}{l}\text { Disinformasi mengenai Prosesi } \\
\text { Upacara Yadnya }\end{array}$ \\
\hline Metode & Model Forest Tree & Tree Diagram & Tree Diagram \\
\hline Kekurangan & $\begin{array}{c}\text { Banyaknya entitas terkait, } \\
\text { dimana diperlukan rentetan } \\
\text { data yang jelas untuk } \\
\text { membentuk sebuah informasi. } \\
\text { Susahnya penerapan model } \\
\text { dalam sistem informasi. } \\
\text { Ketika dimasukkan model Tree } \\
\text { baru kedalam Forest Tree, } \\
\text { model Forest Tree perlu dikaji } \\
\text { ulang untuk penerapan dalam } \\
\text { sistem informasi. }\end{array}$ & Terdapat banyak pemodelan & $\begin{array}{c}\text { Entitas yang terkait dengan model } \\
\text { sangat sedikit, sehingga informasi } \\
\text { yang disajikan berfokus pada } \\
\text { Prosesi Upacara Yadnya, tidak } \\
\text { dengan keterkaitan yang terjadi } \\
\text { antara Proses Upacara Yadnya }\end{array}$ \\
\hline Kelebihan & $\begin{array}{c}\text { Hanya diperlukan satu } \\
\text { pemodelan, sehingga } \\
\text { memudahkan untuk } \\
\text { mengetahui jalannya sistem. } \\
\text { Entitas yang terkait dengan } \\
\text { model Forest Tree terjadi } \\
\text { integrasi dua arah (keterkaitan } \\
\text { antara child-child) yang } \\
\text { memudahkan pengguna melihat } \\
\text { informasi secara detail. }\end{array}$ & $\begin{array}{l}\text { Penerapan model yang mudah } \\
\text { dalam sistem informasi. } \\
\text { Penerapan model bisa dilakukan } \\
\text { secara berkelanjutan dengan } \\
\text { berbagai platform yang ada. }\end{array}$ & $\begin{array}{l}\text { Hanya terdapat satu buah model, } \\
\text { sehingga penerapan model menjadi } \\
\text { mudah pada sistem informasi. } \\
\text { Keberlanjutan dari model ini sangat } \\
\text { mudah diaplikasikan bahkan } \\
\text { diperbaharui. }\end{array}$ \\
\hline
\end{tabular}

Tabel 1 Perbandingan model Forest Tree dengan model Tree

Tabel 1 merupakan perbandingan penerapan antara model Forest Tree dengan mode Tree pada sistem informasi. Model Forest Tree sendiri memiliki keunggulan dengan tidak mengindahkan kaidah model Tree dimana kaitan antara child dengan child dalam suatu parent tidak diperbolehkan. Oleh karena itu memudahkan proses integrasi antara entitas Gamelan Bali dengan Upacara Yadnya untuk melakukan proses Copy atau References. Model Tree sendiri berfokus pada proses References untuk melakukan kaitan antara parent dengan child, sedangkan model Forest Tree sendiri bisa melakukan proses Copy untuk studi kasus Upacara Yadnya yang unik dengan Gamelan Bali tertentu. 


\subsection{Output Sistem Informasi}

Output dari Sistem Informasi Gamelan Bali Terintegrasi dengan Model Forest Tree sebagai basis dari sistem informasi akan dibahas pada gambar sebagai berikut.
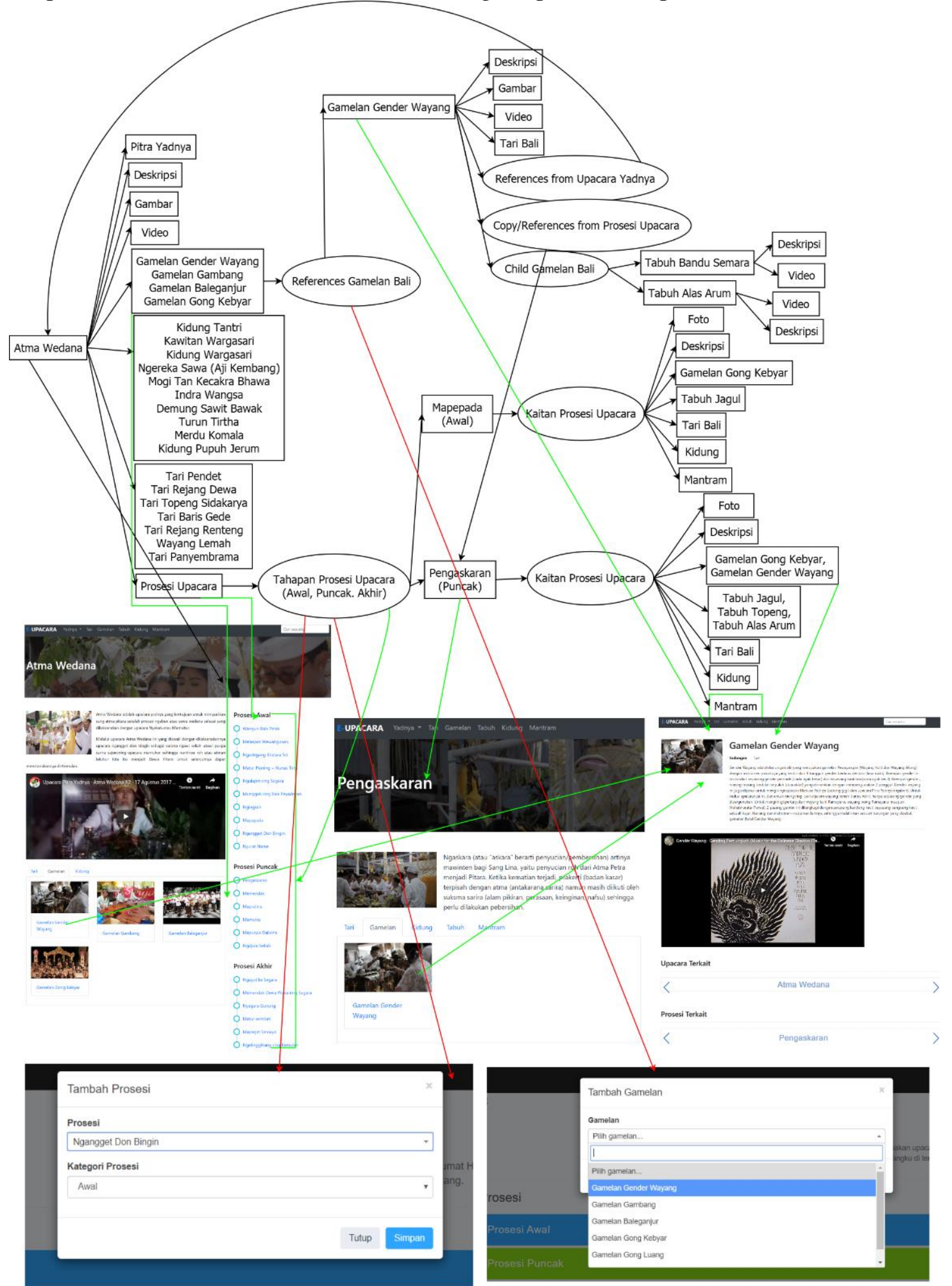

Gambar 10. Hasil Penerapan Model Forest Tree pada sistem informasi.

Gambar 10 merupakan hasil penerapan dari model Forest Tree pada sistem informasi, 
dimana terjadi beberapa hal mulai dari kaitan antara child dengan child hingga proses CopyReferences yang terjadi. Proses evaluasi sistem dilakukan dengan memerhatikan berjalannya kaitan antar entitas serta proses Copy-References. Proses kaitan child dengan child dalam parent dapat dilihat dari entitas Prosesi Upacara, dimana memiliki child entitas Gamelan Bali, Tari Bali, Kidung, dan Mantram. Tetapi pada entitas Gamelan Bali memiliki child yaitu entitas Tabuh yang berkaitan langsung dengan entitas Tari Bali. Sehingga disini letak keunikan dari model Forest Tree dalam sistem informasi ini. Proses Copy-References terjadi antara entitas Prosesi Upacara dengan entitas Gamelan Bali. Hali ini dikarenakan untuk mengakomodir kejadian unik atau khusus, dimana dalam fakta dilapangan suatu Prosesi Upacara bisa digunakan dalam banyak Upacara Yadnya, tetapi terjadi perbedaan penggunaan Gamelan Bali beserta child dari entitas Gamelan Bali yaitu entitas Tabuh. Hasil evaluasi yang didapatkan adalah berjalannya proses keterkaitan antara antara child dengan child dalam suatu parent serta proses Copy-References dalam sistem informasi.

\section{KESIMPULAN}

Permasalahan yang dihadapi oleh masyarakat khususnya di Bali mengenai penggunaan Gamelan Bali dalam suatu Upacara Yadnya menyebabkan penelitian ini ada. Penelitian mencakup banyak entitas seperti Gamelan Bali, Upacara Yadnya, Prosesi Upacara, Tabuh, Tari Bali, Kidung, dan Mantram. Solusi untuk memecahkan banyaknya entitas dengan kondisi khusus (banyak parent dan child dalam suatu entitas) adalah dengan menggunakan model Forest Tree.

Model Forest Tree adalah cara baru untuk menghubungkan banyak pohon (Tree) dalam satu atau lebih entitas. Model Forest Tree berasal dari model Tree dengan kondisi antara satu child dengan child atau keterkaitan antara parent dengan child yang terkait dengan parent lainnya (tidak mengikuti aturan model Tree secara umum). Model Forest Tree itu sendiri dalam penelitian ini dapat dikatakan tidak berhubungan langsung dengan metode Forest Tree. Ini karena metode Forest Tree berhubungan langsung dengan pemrosesan dan peramalan sedangkan model Forest Tree berhubungan dengan entitas dan data.

Pembuatan model Forest Tree itu sendiri tidak hanya karena ketidakcocokan aturan model Tree dalam sistem ini, tetapi juga karena sistem informasi ini memiliki banyak entitas dan tujuannya adalah untuk memberikan informasi yang tepat dengan menyertai hubungan antar entitas. Hal ini didasarkan pada pengembangan model Forest Tree pada gabungan dari dua model Tree yaitu model Tree Gamelan Bali dan model Tree Upacara.

Sistem informasi ini didirikan dengan menggunakan sistem Web, dengan tujuan memberikan informasi dan edukasi kepada masyarakat. Melalui proses penelitian dalam sistem informasi ini, ada kesimpulan bahwa sistem informasi ini dibangun untuk memberikan informasi kepada masyarakat umum tentang entitas yang terkait berdasarkan model pengembangan Tree dari Gamelan Bali dan Upacara Yadnya. Dengan penelitian ini, model Forest Tree dapat digunakan untuk proyek lain yang perlu menghubungkan lebih banyak entitas (beserta banyak parent dan child) dan memiliki kerumitan dalam data, terutama pada entitas yang mengandung begitu banyak data dan keterkaitan antara data tersebut.

\section{DAFTAR PUSTAKA}

[1] I. Ayu Sofiani Dewi Yulandari, "Pembangunan Aplikasi Virtual Gamelan Bali Berbasis Android," Universitas Komputer Indonesia, 2018.

[2] I. W. Basyari, "Menanamkan Identitas Kebangsaan melalui Pendidikan Berbasis NilaiNilai Budaya Lokal," Edunomic Jurnal Pendidikan Ekonomi, vol. 1, no. 2, 2013.

[3] W. G. Pratama, and A. K. O. Sudana, "Pemodelan Sistem Informasi Gamelan Bali Menggunakan Tree Diagram," Merpati, vol. 2, no. 2, 2014.

[4] T. Lijoed, D. Paseru, and T. C. Suwanto, "GAME PENGENALAN RAGAM BUDAYA DAN ALAM SULAWESI UTARA,” Jurnal Ilmiah Realtech, vol. 14, no. 1, pp. 54-63, 2018. 
[5] S. Aisyah, "Pengembangan Media Pengenalan Kearifan Lokal Budaya Cirebon Berbasis Android Sebagai Media Pendidikan Karakter Bagi Mahasiswa," LOGIKA Jurnal Ilmiah Lemlit Unswagati Cirebon, vol. 17, no. 2, pp. 37-41, 2016.

[6] A. Christian, "Perancangan Sistem Informasi Website Seni Budaya Prabumulih pada Dinas Pendidikan dan Kebudayaan Kota Prabumulih," InfoTekJar: Jurnal Nasional Informatika dan Teknologi Jaringan, vol. 3, no. 1, pp. 81-84, 2018.

[7] A. Andriani, "Sistem Pendukung Keputusan Berbasis Decision Tree Dalam Pemberian Beasiswa Studi Kasus: AMIK "BSI Yogyakarta”." pp. 163-168, 2013.

[8] Z. Aung, and W. Zaw, "Permission-based android malware detection," International Journal of Scientific \& Technology Research, vol. 2, no. 3, pp. 228-234, 2013.

[9] Z.-P. Liu et al., "Prediction of protein-RNA binding sites by a random forest method with combined features," Bioinformatics, vol. 26, no. 13, pp. 1616-1622, 2010.

[10] R. W. Andrioko, "Aplikasi Pengenalan Alat Musik Tradisional Indonesia Berbasis Android," Universitas Sebelas Maret, 2015.

[11] A. A. K. Oka Sudana, "IMPLEMENTASI STRUKTUR TREE PADA RANCANG BANGUN SISTEM PENELUSURAN SEJARAH PURA KAWITAN DAN KAHYANGAN JAGAT BERBASIS WEB," Lontar Komputer : Jurnal Ilmiah Teknologi Informasi, 2012.

[12] A. Oka Sudana, I. Sukarsa, and I. Wahyu Saputra, "Information System of Yadnya Ceremony on Android-Based," International Journal of Hybrid Information Technology, vol. 7, no. 6, pp. 155-164, 2014.

[13] I. SUKARSA et al., "WEIGHTED TREE SIMILARITY SEMANTIC SEARCH FOR ECOMMERCE CONTENT," Journal of Theoretical \& Applied Information Technology, vol. 55 , no. $3,2013$.

[14] A. K. O. Sudana, I. W. G. M. Kepakisan, and N. K. D. Rusjayanthi, "Implementation of Tree Structure and Recursive Algorithm for Balinese Traditional Snack Recipe on Android Based Application," International Journal of Interactive Mobile Technologies (iJIM), vol. 10, no. 4, pp. 43-47, 2016.

[15] G. Biau, "Analysis of a random forests model," Journal of Machine Learning Research, vol. 13, no. Apr, pp. 1063-1095, 2012.

[16] I. M. Sukarsa et al., "Evaluation of E-Government Maturity Models in Sub-District Public Services in Indonesia Using the SPBE Framework," Jurnal RESTI (Rekayasa Sistem Dan Teknologi Informasi), vol. 4, no. 2, pp. 243-253, 2020.

[17] I. G. A. ANOM, "EFEKTIVITAS PROGRAM SIGARET (SIMPANAN NGABEN NGERIT) DALAM PELAKSANAAN UPACARA PITRA YADNYA DI BR. PEGESANGAN DESA TEMESI, KABUPATEN GIANYAR,” Unhi Press, 2018.

[18] I. D. M. Suara, I. P. Gelgel, and I. W. S. Yasa, "Pitra yadnya implementation for Hindu heroes," International journal of social sciences and humanities, vol. 2, no. 3, pp. 136$148,2018$.

[19] I. GEDE, and A. SUGIARTHA, "BALINESE DANCE AND MUSIC IN RELATION TO HINDUISM,” 2017. 